\title{
ESCRITA NO CORPO: GOZO E LAÇO SOCIAL
}

Rita Manso e Heloisa Caldas

Rita Manso

Psicanalista,

doutora em Teoria

Psicanalítica

(UFRJ), professora

associada do

Programa de

Pós-graduação em

Psicanálise e do

Departamento de

Psicologia Clínica

do Instituto de

Psicologia (Uerj),

professora associada

do Departamento

de Fundamentos da

Educação (UniRio).

Heloisa Caldas

Psicanalista,

doutora em

Psicologia (UFRJ), professora adjunta do Programa de Pós-graduação em Psicanálise e do Departamento de Psicologia Clínica do Instituto de Psicologia (Uerj), membro da

Associação Mundial de Psicanálise

(AMP).

RESUMO: Procura-se discutir, à luz das contribuições da psicanálise, como algumas formas de escrita no corpo, tão frequentes na contemporaneidade — tatuagens, cortes, escarificações — , poderiam produzir maneiras possíveis e singulares de enlaçamento do sujeito ao Outro. A escrita deixa pistas, vestígios do percurso da pulsão, rastos do pensamento e possibilita alguma ligação com o mundo compartilhado, dando margem a pensar numa contenção do gozo através destes tipos específicos que compõem um repertório de traços. Em muitos casos, esses atos de escrita suprem a função paterna permitindo que aqueles em que a voz do Outro não escreveu uma identificação unária na carne tenham acesso ao corpo próprio.

Palavras-chave: Escrita, gozo, corpo, psicanálise, contemporaneidade.

ABSTRACT: Writing the body: jouissance and social bond. The objective of this paper, based on Psychoanalysis contributions, is to discuss the contemporary body writing, such as cuts, scarifications and tattoos, to discuss how they can help to make possible and singular the social bonds between subjects and the Other. Writing leaves tracks, vestiges of the drive paths, remnants of thinking and enables some connection to the common world, giving way to restraining jouissance by means of a repertoire of traces. In many cases, these acts of writing supply the paternal function allowing those who did not undergo the unary inscription of the voice of the Other in their own flesh, so they can have access to their own body.

Keywords: writing; jouissance; body; psychoanalysis; contemporary times. 
P retende-se abordar os efeitos da linguagem no corpo valendo-se prioritariamente dos conceitos psicanalíticos de Lacan sobre a escrita. Partimos do pressuposto de que o sujeito contemporâneo vem adotando diversas formas de escrita para encontrar, na pluralidade crescente de significantes, a especificidade de seu desejo e um sentido para seu gozo. Desta forma, tecemos considerações sobre a escrita no corpo, tão frequentemente encontrada na forma de tatuagens e cortes, como maneiras possíveis e singulares de enlaçamento do sujeito ao Outro, marcando uma forma possível de estabelecimento de laço social. Nosso objetivo é refletir sobre questões que a clínica vem nos colocando cotidianamente, sobretudo com adolescentes e jovens.

Como ponto de partida, gostaríamos de distinguir algumas acepções de escrita para sublinhar o que vem a ser escrita para Lacan e em seguida pensá-la em função do corpo próprio que se inscreve no corpo social.

Destacamos algumas acepções de escrita: 1) a da escrita cartorial e oficial dos documentos, na qual os significantes amarram um sentido e asseguram, pelo Direito, os fatos da vida. Nela já se registram aspectos importantes no destino dos corpos como a identidade sexual ou a indicação da cor da pele; 2) a da escrita pessoal, mais próxima do discurso e da fala, que pode ser questionada como verdade ou mentira por aquele que a lê e interpreta — encontramos essa escrita nas cartas, nos diários, nas anotações e, atualmente, no mundo virtual dos blogs, sites, orkuts, tweeters, facebooks, etc.; 3) a da escrita literária, ficcional por excelência, na qual a referência perde valor e importância; 4) a da escrita matemático-científica, presente nas fórmulas que intervêm sobre o mundo e seus objetos, sem compromisso algum com o sentido ou a verossimilhança, mas com os efeitos que produzem.

Sabemos que as duas primeiras, a escrita cartorial e a pessoal, são políticas, ideológicas, dependem de afirmações discursivas e sociais; variam ao sabor de movimentos políticos que atualizam verdades como ficções compartilhadas. Sabemos também que a linguística estrutural, assim como as teorias que nela se inspiram, abandonou a busca pela referência, concebendo uma autonomia da linguagem em relação ao real. A significação é, portanto, um fato conceitual produzido exclusivamente pelo verbal. Para a psicanálise, na qual a realidade é psíquica, interessa apenas a escrita ficcional. Trata-se de uma escrita comparável à literária por derivar da criação singular de um sujeito por meio da qual se estrutura seu desejo, seu gozo e sua inserção social.

Encontramos no ensino de Jacques Lacan muitas considerações sobre a escrita. Em seu primeiro ensino, ele depreende a escrita da lógica significante ao comentar um conto de Edgar Alan Poe, “A carta roubada” (LACAN, 1957/1998, p.13-66). Nesse conto, ele estuda a carta/letra em seu endereçamento, articulando o significante ao discurso. Embora ele se valha do termo lettre - letra 
ou carta em francês — , termos tradicionalmente ligados ao campo da escrita, encontramos nessa abordagem de Lacan uma preocupação maior com a fala. $\mathrm{O}$ que Lacan destaca como letra no significante é seu caráter diferencial que depende de um traço distintivo, o que vigora tanto na fala (com o fonema) como na escrita (com o grafema).

Esta não será, no entanto, a concepção definitiva de Lacan sobre a escrita. A diferença entre a fala e a escrita vai se delinear em seu ensino desde $A$ instância da letra no inconsciente, texto considerado por ele como "entre escrita e fala" (idem, p.496), até o final de seu ensino, quando essa diferença encontra-se radicalizada na afirmação: “Há mais que uma nuance, há uma montanha entre a fala e a escrita” (LACAN, 1975, p.43).

É bem conhecida a definição do significante para Lacan: aquilo que representa o sujeito para outro significante. Consequentemente, a essência da linguagem não é representar a realidade ou passar um sentido prévio à comunicação, mas unicamente representar um sujeito, ele próprio reduzido ao puro fato de falar com outro. A linguagem, em sua essência de fala, é o sujeito (BORCH-JACOBSEN, 1991). Um sujeito é, portanto, o vazio no qual irá deslizar a cadeia de significantes. No entanto, uma vez que a pulsão passa pela linguagem, essa cadeia remete também ao real da pulsão servindo ao gozo.

Nesse ponto, algo se distingue entre o significante a serviço da cadeia que gera significação e o que nele é da ordem da letra. Quando Lacan aponta, em seu Seminário 20, que “o significante, no sentido auditivo do termo, não tem relação com o que significa” (LACAN, 1972-73/1985, p.31) nos remete à face letra do significante. Dizer que os significantes não têm nenhuma relação com os significados é sublinhar "a face real do significante”. O significante tem assim uma dupla face: por um lado, é o que pertence ao simbólico, constrói o sujeito e sua verdade, presta-se ao laço social; por outro lado, é o que pertence ao real, pode ser considerado como o saber da repetição inconsciente, matema de gozo para um sujeito. Nesse mesmo seminário, Lacan vem então dizer que o significante é a causa de gozo. Na teorização lacaniana, daí por diante, é a letra no significante que começa a funcionar. O significante não deixa de servir à fala, mas pode também ser elevado à dignidade da letra. A partir dessa articulação, pode-se dizer que o significante é o que se engendra da escrita.

Ainda no Seminário 20, ao evocar seu texto "Lituraterra", Lacan fornece uma precisão sobre o que nos interessa: "A escrita é um traço no qual se lê um efeito de linguagem” (idem, p.110). Por isso, requer leituras que podem até variar, mas a lógica que as sustenta permanece a mesma. O exemplo clássico é o da escrita do matema da fantasia ( $\boldsymbol{\phi}_{\hat{\vee}} \mathrm{a}$ ), no qual temos duas letras e uma articulação possível e impossível entre elas. 
Tudo se passa, com efeito, como se a fala devesse ser tomada como uma articulação entre duas escritas. Primeiro a escrita inconsciente, que empurra à leitura e constitui o trabalho de decifração; e depois a escrita que talvez torne possível, pela fala, que um saber como meio de gozo se escreva, o que constitui um tipo de cifração. Em ambas, o gozo é uma constante. Tanto cifrar como decifrar são operações que contêm, dão passagem, servem de via ao gozo pulsional.

Também podemos ler essas operações de ciframento e decifração como as duas operações lógicas de causação do sujeito: a alienação e a separação (LACAN, 1964/1988, p.193-217). Elas permitem que, da diversidade do cultural, se extraia a unidade do sujeito. Operações de linguagem nas quais a identificação parte da alteridade, mas também operações de afeto, na medida em que incidem sobre o corpo em seu gozo. Ao mesmo tempo em que são operações que permitem uma inscrição, elas também deixam um resto, ou um rasto. Estes rastos são significantes da passagem de algo ou alguém na vida do sujeito e podem ser "lidos" pelo outro, que lhes atribuirá um significado, como pistas para uma análise. Desta forma, o sujeito da psicanálise surge da alienação fundamental ao Outro, sendo que "as bordas corporais são, por princípio, bordas sociais, tendo em vista que são efeitos de nossa relação à linguagem — lugar desse Outro primordial — que é, desde o início, produtora de laço social” (COSTA, 2005, p.23).

\section{RASTOS NO CORPO}

A palavra 'rasto' origina-se no latim rastru, nome de um instrumento para quebrar torrões de terra (HOLANDA, 1975, p.1189). Corresponde a uma variação da palavra rastro, mas é a forma mais usada quando se quer equivaler ao sentido de vestígio, indício ou sinal. Há outro uso, como quando alguém segue outro alguém 'a rastos', ou seja, com o sentido de 'rastejando'. No sul do Brasil, a expressão 'enredar o rasto a ...' significa despistar, enganar ou lograr. Em inglês, pode ser track, sign, vestige, sendo esta última a que escolhemos para a versão inglesa do título deste artigo, em virtude da semelhança com o português vestígio.

A escrita deixa pistas, vestígios do percurso da pulsão, rastos do pensamento. Possibilita alguma ligação com o mundo compartilhado, inscreve o sujeito em algum laço social já que quem escreve deixa provas, evidências do desejo de que alguém o leia, ainda que se trate da escrita de um psicótico.

Escrever impõe, assim, algum domínio sobre o real. Se não nos impede de depararmo-nos com ele, o real, pelo menos nos auxilia a elaborar a situação traumática, refazendo os acontecimentos até o ponto em que deixamos por conta do outro a continuidade da reflexão. É o que Freud deixa claro ao recuar na continuidade de suas associações no sonho de injeção de Irma, quando desafia que "se alguém se vir tentado a expressar uma condenação apressada de minha cautela, 
eu o aconselharia a fazer a experiência de ser mais franco do que eu" (FREUD, 1900/1994b, p.130). Ele se poupava de uma superexposição desnecessária e, ao mesmo tempo, deixava por conta do leitor uma contribuição própria em sua leitura do caso. O outro, como leitor, deve também contribuir na elaboração de seu próprio texto sobre a experiência exposta, sobre aquilo que foi lido.

Há, então, um produto da leitura da escrita que varia de sujeito para sujeito. As ressonâncias do que foi lido de significante gerará significados diversos. "Tratase de saber o quê, num discurso, se produz por efeito da escrita”, desenvolve Lacan (1972-73/1985, p.47). Prossegue ainda afirmando que "se há alguma coisa que possa nos introduzir à dimensão da escrita como tal, é nos apercebermos de que o significado não tem nada a ver com os ouvidos, mas somente com a leitura, com a leitura do que se ouve de significante" (idem), o que nos leva a crer ser este um dos acessos possíveis ao âmago do sujeito. Um exemplo é o do artista que cria pontos de identificação para o seu leitor, solidário na insatisfação com a renúncia da satisfação pulsional exigida pelo processo civilizatório. Da mesma forma, ainda que não seja necessariamente como arte, o sujeito encontra na escrita um meio propício e adequado para expurgar sua dor, elaborar suas perdas, conservar suas alegrias.

Atualmente, programas que documentam o dia a dia de tatuadores com seus clientes vêm se destacando na televisão paga; são quase verdadeiras sessões de análise dos motivos que conduzem o sujeito ao ato de se tatuar (Miami Ink, Los Angeles Ink e até um programa realizado no Rio de Janeiro). Eles, os tatuadores, escutam enquanto vão deixando seu stylo na pele do freguês, com inúmeras agulhadas, punturas, que acolhem a sua arte. Sempre há um motivo para a escolha do tema: o retrato da mãe, de um filho recém-nascido, um animal querido, um símbolo de poder, de conquista, de lembrança para perseverar no desejo. Mas há também os que fazem apenas desenhos na pele, deixando marcas onde se provoca a formação de queloides cicatriciais.

Num livro clássico sobre Tatuagens e desenhos cicatriciais (1966), os mineiros Alencar Neto e Nava esclarecem os vários tipos de atos efetuados sobre a superfície cutânea: desenhos, colorações e pinturas, definitivas ou temporárias, que são as tatuagens. Já os desenhos cicatriciais, cicatrizes cirúrgicas, são propriamente as escarificações, intencionais ou não. Mas por que se marcar de forma definitiva? Os motivos variam. Os antigos o faziam para discriminar castas, o pertencimento à nobreza. Na África, as pinturas podem tanto significar uma vestimenta de guerra como de comemoração. As tribos criam temas específicos para representarem-se, como os xadrezes nas saias Kilt cujos diagramas e cores indicam o pertencimento a um determinado clã na Escócia. Entre os maoris da Nova Zelândia, as tatuagens corporais representam o destaque dado à identidade étnica, o orgulho de pertencer a uma raça, com seus costumes e tradições, incluindo o uso de tatuagens 
diferenciadas conforme o sexo: mulheres nos lábios e queixos, preferencialmente; homens em parte do corpo, da cintura para baixo, e no rosto. Boa parte de nós se lembra do ator Harvey Keitel em “O piano” (CAMPION, 1993), no papel de um aborígine cujo corpo era todo coberto por desenhos maoris.

É assim que, no contexto da falta de uma escrita que possa amarrar o corpo, o gozo e o Outro, as manifestações de corte no corpo, tão frequentes atualmente, vêm nos chamar a atenção. Notícias recentes (O Dia, 14 de fevereiro de 2009) divulgaram pela mídia o caso de uma jovem brasileira vivendo em Zurique, Suíça, com o namorado. Ao que todas as evidências indicam, retalhou seu corpo com letras e símbolos de um partido neonazista, pretendendo, aparentemente, ganhar uma indenização do governo suíço. Os jornais noticiaram que a jovem disse estar grávida de gêmeos e responsabilizou a situação traumática como causadora de um aborto, além de tê-la deixado com cicatrizes que escancaram a discriminação racial e política. A princípio, inflado pela indignação de uma atitude incomodamente próxima do apartheid, o então presidente brasileiro e seu Ministro da Justiça reagiram, tomando o partido da jovem, exigindo que as autoridades suíças apurassem o fato com o devido rigor. Depois, à medida que o caso se esclarecia, todos foram se calando, se encolhendo, se vexando, se espantando diante da trama urdida pela jovem. Talvez, o mais pasmo fosse o próprio pai, ao considerar que "em qualquer circunstância, a minha filha é vítima”, disse aos repórteres — “Ou é vítima de graves distúrbios psicológicos, ou da agressão”, a respeito da qual, a princípio, não se tinha motivos para duvidar. O que pretendia ela com toda essa encenação?

Por certo, não chegaremos a nenhuma conclusão, uma vez que não se trata de um caso clínico. Não podemos diagnosticar e nem decidir se, de fato, houve uma encenação, situando seu gesto do lado do acting out ou da passagem ao ato. No entanto, sabemos o quanto a incidência da dor física amortece a dor psíquica. O próprio Freud (1920/1994b) estranhou o fato de que os soldados que voltavam da Primeira Grande Guerra com algum ferimento tendiam a não desenvolver a 'neurose de guerra'. Chegou a conjeturar que talvez a dor física servisse como uma espécie de vacina contra a necessidade de formação da doença psíquica. Isto fica mais instigante em uma história descrita na revista feminina Marie Claire (edição 216, de março de 2009), matéria decorrente e inspirada na situação vivida pela brasileira descrita acima. Ali, é relatada a história de Beatriz, jovem artista plástica de 25 anos, que se automutila desde os 12. Nessa época, após ter o resultado decepcionante de uma nota na escola, começou a bater sua cabeça na parede até que a dor física suplantasse a decepção consigo mesma. Dez anos mais tarde, adotou lâminas e objetos afiados para se cortar como forma de lidar com a angústia. A jovem admitia que, depois do corte, sentia-se aliviada. Com os anos e a frequência, passou a se cortar também nos momentos de felicidade, como 
uma forma de ampliar o sentimento, traduzindo aqui uma roupagem erótica: procurava estar só para fazer o corte, pois "gostava de ver o sangue escorrer e até brincava às vezes com ele". Diz não se cortar há um ano e três meses, um tempo depois de ter iniciado sua análise, usando a escrita para colocar no papel todas as vezes em que pensa em se mutilar, mas sem fazê-lo. Consequentemente, acontecimentos como estes, da jovem brasileira e da artista plástica, nos servem para pensar a função do corte em sua relação com a função significante. ${ }^{1}$

A função do corte é, por excelência, a função que cabe ao significante quando sua incidência sobre a carne faz dela corpo. Não há corpo sem que a função do corte não tenha operado, resultando numa perda. Ao tratar da angústia, no Seminário 10, Lacan considera o corte sobre o corpo uma operação que deixa um resto, o objeto a, de cuja presença a angústia é o sinal (LACAN, 1962-63/2005). Trata-se de uma perda corporal, uma perda na economia de gozo, não redutível à palavra, uma vez que o gozo é heterogêneo ao significante. Só há corpo se a função do corte operar. Nesse sentido, a operação de corte, ainda que feita pelo significante, se diferencia da operação de identificação, também efetuada pelo significante. Miller (2005) ressalta a função de corte do significante como distinta da função de traço — Aufhebung — que tem por efeito anular e elevar. Como traço, o significante promove uma identificação ao sujeito. O corte promove a separação da qual resta algo — um resto corporal inassimilável pelo simbólico (MILLER, 2005, p.16).

O corte aparece, assim, na relação entre o corpo próprio e o corpo simbólico do Outro como o resultado das operações de alienação e separação. Se na face da alienação temos mais o aspecto da identificação, na separação predomina a perda, não só deste resto corporal como da possibilidade de nomeá-lo. O corte tem, assim, a função de isolar no corpo o que dele se separa do Outro e o que no Outro é impossível à nomeação do gozo.

É nesse ponto que Lacan enlaça a tatuagem e a escarificação como formas mais antigas de encarnar no corpo a libido, tomada por ele, nesse contexto, como um órgão. Ele observa que:

“o entalhe tem muito bem a função de ser para o Outro, de lá situar o sujeito, marcando seu lugar, no campo das relações de grupo, entre cada um e todos os outros. E, ao mesmo tempo, ela tem, de maneira evidente, uma função erótica, de que todos aqueles que abordaram sua realidade se aperceberam" (LACAN, 1964/1988, p.195)

\footnotetext{
${ }^{1}$ Para este trabalho não consideramos os sujeitos que se cortam como uma forma de arte (body art).
} 
Os semblantes do corpo, através de cortes e tatuagens, revelam o maior ou menor fracasso dos sujeitos em seus arranjos para dar conta de uma dupla falta, a real e a do Outro. Como essas faltas obedecem a uma sequência lógica, admite-se que a primeira surge como decorrência lógica da segunda. Na alienação, através da busca de um significante do Outro, revela-se a falta real, anterior, do vivo diante da reprodução sexuada e do fato de que, como indivíduo, ele é destinado à morte. A primeira falta é real e diz respeito à perda de gozo no corpo. É sobre ela que recai a segunda falta, a do Outro, como impossibilidade de simbolização.

Podemos pensar então, nos casos de excesso em que os sujeitos se cortam compulsivamente, que a tentativa simbólica fracassa pelo fato de que a primeira operação de extração de um objeto a também fracassou. Esta seria uma das razões pelas quais o ato de cortar se repete, reiterando um apelo ao simbólico, diante da falta de uma letra que marque um litoral entre o corpo de gozo e o corpo simbólico, impedindo a construção de margens para o percurso da pulsão.

\section{O CORPO ENTRE SEMBLANTE E SINTOMA}

O conceito de corpo em Psicanálise está intimamente conectado ao de escrita desde os seus primórdios quando Freud concebeu o sintoma histérico no corpo como uma mensagem inconsciente (FREUD e BREUER, 1895/1993). O inconsciente é então um leitor das experiências vividas pela carne, traumáticas pelo excesso e pela precariedade do lugar em que puderam ser escritas quando do nascimento do sujeito. Os traços que as marcaram portam uma ambiguidade de origem. Ao mesmo tempo em que se oferecem à leitura, apresentam-se precários, por estrutura, para dar sentido à experiência. Eles veiculam, assim, nos sintomas e demais formações do inconsciente, o irrepresentável radical do gozo.

Lacan avança na teoria de uma escrita correlacionada ao inconsciente e ao corpo. Desde cedo, em Função e campo da fala e da linguagem em psicanálise (1953/1998), ele comenta que o inconsciente é o capítulo censurado de uma história, cuja verdade a resgatar já está escrita em outro lugar, e situa essa escrita no sintoma como monumento, nas lembranças como arquivo, no estilo de vida, na lendária novela familiar, nas reminiscências. Mais adiante, ele acrescenta que o sintoma é "símbolo escrito na areia da carne e no véu de Maia” (LACAN, 1953/1998, p.260-261).

Podemos destacar desta citação duas expressões — areia na carne, véu de Maia —, pois ambas indicam uma escrita que falseia, digamos assim. Seja porque ela se apaga facilmente, como a escrita na areia que o vento sopra e a onda lava, seja porque ela é mentirosa, ofuscando com sua imagem a verdade. A expressão véu de Maia indica, na filosofia oriental, a realidade ilusória que encobre as coisas em si. Nessa ocasião de seu ensino, Lacan trabalha o plano significante como permi- 
tindo uma exegese que "resolve" hermetismos, "dissolve" equívocos, "absolve" artifícios do discurso e "libera" um sentido aprisionado (idem, p.282).

Muitos anos depois, essa perspectiva lacaniana se transforma. O conceito de real como fora do alcance do simbólico não permite mais a concepção de uma verdade oculta na fala. Situado além do significante, o real depende dele, mas não se reduz jamais a ele. O real é o irrepresentável que o próprio significante traça (MILLER, 2000). A partir dessa reformulação do conceito de real, no Seminário 17: O avesso da psicanálise (1969-70/1992), Lacan se dedica a pensar como os discursos operam, no laço social, conciliando um paradoxo: enlaçar pelo significante, no campo do Outro, o impossível de representar do gozo autista do corpo. Nas fórmulas dos discursos, ele situa a linguagem, o sujeito e um irrepresentável expresso pelo objeto $a$ - ponto em que a linguagem encontra o silêncio pulsional no corpo.

No Seminário 18: De um discurso que não fosse semblante (LACAN, 1970-71/2009), avança nessa articulação entre o discurso e o real. Se o primeiro não passa de aparência, semblante, jogo significante por excelência, o segundo, nos diz Lacan, é fixado por uma escrita de outra ordem, uma escrita desprovida de sentido, mas que tem efeitos no real. A partir daí, a tese forte de Lacan sobre a escrita será aquela em que a letra toca o real e causa o gozo. Ele distingue, então, a primeira acepção de escrita, dissolvida na ordem do discurso, de uma escrita de outra ordem: uma escrita do gozo, mais apropriada ao objeto da psicanálise, e que ele vai conceber segundo o modelo da escrita matemática.

Trata-se de uma escrita que não deixa de se articular ao sintoma como semblante, uma vez que o sujeito, como um leitor, é guiado pelo que faz signo e o convoca, ainda que não tenha significação alguma. Nos termos lacanianos: "o que tem semblante de sintoma, isto é, em princípio, coisas que nos dão sinal, ${ }^{2}$ mas das quais não compreendemos nada”. E acrescenta que “é só isso que há de seguro” (LACAN, 1971, 2009, p.49). Assim, Lacan trata e aponta, desde o título do seminário, este paradoxo: todo discurso é semblante? Pura aparência? Não indica nada fora do plano da linguagem? É vazio no que concerne a um referente conjecturável? Ou haveria um discurso que não fosse do semblante? Estamos em um mundo que é um império de semblantes?

A expressão "império de semblantes" foi inspirada no título de um livro de ensaios sobre o Japão, O império dos signos (1970/2007), de Roland Barthes no qual ele analisa a escrita oriental. Barthes trabalha com um conceito de escrita bastante ampliado que abrange todo e qualquer traço como gesto significante, como o desenho das pedras na decoração de um jardim, o mapa de uma cidade, o movimento corporal na mesura dos cumprimentos. Ele privilegia o traço em seu

\footnotetext{
2 “Qui vous font signe” no original em francês, p.32.
} 
endereçamento convidando à leitura e ao acolhimento do outro, ao mesmo tempo em que aponta a um vazio no plano da significação. Nem mesmo a significação produzida pelo verbal, segundo ele, pode ser 'agarrada' por essa escrita.

Tais escritas servem ao laço social, são gestos de cortesia, convidam o olhar para algo a ser admirado, um teatro a se mostrar, sem visar mais que o ato de pura significância. Assim ele comenta, a propósito da organização espacial japonesa:

“que uma técnica secular permite à paisagem ou ao espetáculo produzirem-se numa pura significância, abrupta, vazia, como uma fratura. Império dos Signos? Sim, se entendemos que esses signos são vazios e que o ritual é sem deus [...] não há nada para ser agarrado" (BARTHES, 1970/2007, p.147-148)

Logo, o signo se justifica apenas pela passagem do humano que deixa rastos como em um Jardim Zen: "Nenhuma flor, nenhum passo: Onde está o homem? No transporte das rochas, no rasto do ancinho, no trabalho da escrita" (idem, p.104).

Dentro dessa perspectiva, Barthes avalia a escrita do vazio de significação em vários aspectos da cultura japonesa: pacotes de presentes que valem mais como envoltório do que o presente que contêm; gestos e mesuras de cumprimento e cordialidade que não escondem nem revelam qualquer hipocrisia; jogos de caçaníqueis em que o disparo inicial do atirador, decide sobre a partida; a culinária que se ocupa menos do que cozinha do que do ritual em si. Em especial, Barthes comenta a poética japonesa na qual o haicai, poema breve de três versos, não resulta de concisão, mas da renúncia ao infinito das metáforas agindo sobre a raiz do sentido. Um haicai, ele explicita, não é um "pensamento rico reduzido a uma forma breve, mas um acontecimento breve que acha, de golpe, sua forma justa” (idem, p.99) não se prestando à tagarelice (idem, p.106). "Ao mesmo tempo em que é inteligível, o haicai não quer dizer nada” (idem, p.91). Segundo essa perspectiva, a coisa japonesa não se encontra dentro de um contorno forte. Os limites de dentro e fora não são operantes para ela. Ao contrário, ela flutua no vazio, como as flores e folhas dispostas pela arte do Ikebana em que se produz a circulação do ar (idem, p.59) ou a arquitetura das cidades em torno de um centro, em geral, vazio.

Todas essas considerações parecem combinar com a proposta lacaniana tão marcante do Seminário 18 sobre a letra, distinguindo-a em especial do significante, uma vez que ela não se presta à produção de sentido. No entanto, algo marca a diferença entre a letra, traçada pelo efêmero do gesto do calígrafo, e que reina sobre o vazio do império dos signos de Barthes, e o semblante em Lacan. 
Se, de um lado a letra é índice, rasto, vestígio e para Barthes remete ao vazio, para Lacan ela é signo do sulco de uma rasura pela qual o gozo escoa. Vazia de significado e de sentido, sem dúvida, mas não vazia de gozo. Ela faz borda ao gozo.

Ao comentar esse livro de Barthes, lançado na ocasião, Lacan parafraseia seu título indicando que é impróprio falar de signo naquele contexto. Tratase, segundo ele de "império dos semblantes" (LACAN, 1971/2009, p.118). Ele opõe-se ao vazio que Barthes aponta, indicando que "nada é mais distinto do vazio cavado pela escrita do que o semblante na medida em que, para começar, ela é o primeiro de meus godês a estar sempre pronto a dar acolhida ao gozo, ou, pelo menos, a invocá-lo com seu artifício” (idem).

Vemos então que Lacan vai reservar o termo "signo", assim como "letra" para o gozo - mas ambos, nessa função, não apontam ao vazio, e sim ao gozo em sua positividade. Não há negativo de gozo, o gozo é sempre positivo, ensinou-nos, há pouco tempo, J.-A. Miller (2009). E obedece a uma escrita que modaliza, de forma singular, como um falasser pode vivê-lo. Essa escrita é feita de letras vazias de sentido, certamente. No entanto, em termos do que interessa à psicanálise — o gozo — , elas são correlatas a algo que não pode deixar de estar vivo no real.

Assim, Lacan avança na problemática de como articular o discurso - que não passa de aparência, semblante — , ao real. Cambiável, efêmero, evanescente, o semblante, em relação ao real, não é nem verdadeiro nem falso. Ele promove o laço social, sustenta o sujeito no campo do Outro, mas não corresponde à verdade, assim como não podemos apalpar o arco-íris (LACAN, 1971/ 2009, p.15). No entanto, Lacan vai defender que, mesmo sendo o arco-íris uma aparência, é também, inegavelmente, signo do real. Não importa se ele é verdadeiro ou falso, importa que ele refere-se a algo. O referente, diz Lacan, nunca é o certo quando o traduzimos em palavras. Por essa razão, por ser impossível de designar, ele é real (idem, p.43).

Com relação à psicanálise e seu lugar na produção dos discursos, Lacan afirmará que "a análise se distingue de tudo que foi produzido até agora de discurso, por enunciar isto, que constitui o osso do meu ensino: que eu falo sem saber. Falo com o meu corpo, e isto, sem saber" (1972-73/1985, p.161). Este saber que não se sabe é algo novo no campo dos saberes, pois se baseia no significante como tal, necessitando do corpo para isso. Consequentemente, no que permite pensar a dimensão do corpo, em sua relação com a linguagem, três aspectos podem ser assinalados: o corpo próprio que goza, fora da linguagem; o corpo do Outro, da realidade social, no qual esse gozo se legitima pela linguagem; e o corpo do semelhante, com o qual o semblante regula as parcerias, uma vez que não há prescrição sexual. Segundo esses três aspectos, os corpos se apresentam, 
se impõem, se situam, se movimentam, se dizem, se atritam, se cultuam. Mas, no que diz respeito ao gozo, cada um porta seu enigma.

Assim, as aparências que revestem o corpo podem variar muitíssimo. Dependem das inserções no tecido cultural e mudam segundo o registro, a ocasião, o tipo de laço. Através de semblantes, o corpo próprio se articula ao corpo do simbólico. Os semblantes trazem a marca dessa articulação, pois derivam e se endereçam ao Outro. Promovem uma operação de identificação ao separar um corpo entre outros se valendo de algum arranjo singular, uma bricolagem, a partir de significantes do arsenal do Outro.

O mesmo não ocorre com a experiência de gozo. O sintoma como repetição, a fantasia como enquadre fixado da realidade, são indicações de uma escrita de gozo constante, ainda que de uma forma singular em cada caso. Uma formulação que se escreve, na carne, a partir de experiências inaugurais, e é impossível de se lavar. Assim, em relação ao Outro social, o discurso promove a linguagem no que esta tem de mais variável. Já a escrita é considerada, por Lacan, como matema, ou seja, fórmula matemática que escreve uma função a partir da qual as variáveis gravitam ao redor de uma constante - $\mathrm{f}(\mathrm{x})$ - que amarra o sintoma.

Vale ressaltar aqui duas vertentes do sintoma: de um lado, seu valor de mensagem a decifrar; de outro, sua relação com o gozo. O sintoma como mensagem está evidentemente conectado ao Outro e à linguagem, fornecendo ao semblante suas múltiplas variações. A vertente que se articula ao gozo, ao contrário, é uma constante. Destituída de sentido, esta face do sintoma não serve ao jogo significante. Lacan a concebe como escrita e letra, destacando a função da letra nas fórmulas matemáticas: abstratas, desligadas de sentido, mas operações que têm efeitos no real. Esta faceta do sintoma é também seu aspecto incurável e ao qual, no final de seu ensino, Lacan nomeia de sinthoma (LACAN, 1975-1976, 2007).

\section{AS TATUAGENS}

Gostaríamos então de considerar as tatuagens como escritas corporais que respondem ao Outro contemporâneo visando atender a essas duas vertentes do sintoma: por um lado, elas dão destaque ao semblante corporal em seu enlaçamento ao Outro; por outro, circunscrevem o gozo do corpo próprio.

É preciso considerar que as tatuagens se difundiram e ultrapassaram os limites dos grupos restritos, alastrando-se por toda uma geração. Os programas da televisão paga que citamos antes - Miami Ink, Los Angeles Ink — dedicados aos artistas, tatuadores, e àqueles que os procuram e dos quais os primeiros ouvem a história do desenho escolhido, têm uma audiência considerável. Certamente se inserem no boom da escrita atual que a torna diferente da escrita do século passado. Se antes a escrita se apresentava de forma mais lenta - o que lhe conferia 
um caráter mais perene e documental —, hoje, ela é célere, lavada pelas ondas da moda e inundações de informação, tornando-se ultrapassada a cada estação. Embora ainda seja o que habitualmente chamamos de escrita, muitas de suas manifestações assemelham-se à fala. Leva-as o vento. E onde está a escrita que dura e sustenta o pacto entre os humanos? Vemos seu sistema em crise. Das leis do Direito às identificações sexuais, tudo passa por uma revisão que, na prática, balança séculos de tradição.

Como escritas no corpo, as tatuagens não são apagadas com facilidade. Neste caso, para a geração que as adotou de forma quase generalizada, elas representariam um esforço de sustentar o valor durável da escrita numa época em que tudo flui, passa, liquefaz-se, como pensa Bauman (2000). Uma tentativa de garantir uma escrita que se registrasse como indelével?

Diante do frenesi de tantos ditos, do valor dos significantes que se dilui em relativismo, a tatuagem provavelmente terá o mesmo destino. No entanto, enquanto não se adota, de forma mais usual, o laser para retirá-la, pode ser uma forma de resistir à volubilidade dos tempos, sustentando no semblante do corpo o Um do traço significante, o Einziger zug freudiano fundamental à identificação. Ela serve à demarcação da unidade em meio a tanta diversidade.

Se for este o caso, ela colabora dando mais consistência ao corpo do Um no laço com o Outro, e ao mesmo tempo resguarda o inigualável e indelével daquele corpo. Ela assinala no corpo sua marca de singular, seu caráter de próprio, ao mesmo tempo em que, com essa distinção, traça sua presença no corpo do social, fora de si, no olhar do Outro. A tatuagem permite que o Um do corpo se enlace ao Outro através do olhar que convoca.

Por vezes, ela é usada em áreas do corpo expostas na intimidade, ou seja, uma tatuagem dirigida a alguns, por vezes usada de forma mais ostensiva, saltando da intimidade dos grupos para o campo social mais amplo. Seja como for, o corpo destinado ao gozo, que ela marca, resta fora do sentido. Segundo esse raciocínio, a tatuagem se aproxima do sinthoma, pois identifica um sujeito com a mesma vacuidade de um nome próprio; ela não diz nada sobre o ser, mas o cifra. Como não se trata na atualidade de números, como já foi seu uso em campos de concentração, essa cifra não é contável; ela é letra e demanda decifração, causando o desejo.

Em tempos de domínio das estatísticas, este é um dado relevante. A tatuagem parece propor que se contem histórias recusando-se à enumeração anônima. Servem para escrever promessas de amor, desacreditadas na fala, nas alianças e nos documentos. Muitas delas indicam a presença, no corpo do amante, de algo do amado, envelopando assim a imagem do corpo do outro: i(a). São nomes de pessoas, filhos, parceiros. Imagens nas quais uma identificação narcisista opera: o signo do zodíaco, uma fada, uma flor, um animal, um desenho tribal. O Ideal 
do Eu as reveste, projetando o ponto em que se querem ver amados: como pai, mulher, amante, aquariano, zen, entre outros.

Um jovem deu um exemplo da tatuagem conectada ao sintoma em sua decifração ao relatar: "Minha primeira tatuagem foi a de um tubarão porque é um animal solitário, que se vira sozinho, é guerreiro. Isso dizia muito de mim.” Afirmação subjetiva que podemos revirar: solitário como todo sujeito, recebo do Outro minha imagem invertida e a ela respondo sintomático tomando-a no plano de uma idealização: da agressividade especular ao animal guerreiro; da solidão à autonomia daquele que se vira sozinho; do dizer autista à tatuagem mais pública no meio do peito. Em outro caso, uma jovem e seu parceiro tatuaram a palavra 'família' em caracteres orientais na promessa de vir a construir uma. Ou ainda outro sujeito que se tatuou para marcar para seus pais sua autonomia subjetiva, tatuando em seu corpo uma palavra: 'determinação'. Além do texto herdado de seus pais, passou a escrever seu próprio texto. Mas por que no corpo? Para nunca esquecer, pois se corre o risco de não deixar vestígios, apagando-se os rastos na memória.

São tatuagens a serviço da identificação cujo traço pode ser pensado como a serviço do Ideal do Eu que é Ideal do Outro — I (A) — como Lacan sublinhou. Ao usar a expressão Ideal do Outro, Lacan considera que a identificação só pode ocorrer na medida em que o Eu se molda pela sedimentação de ditos que advêm do Outro e que o alcançam originalmente, via de regra, como voz. E aqui tomamos a voz em diversos planos: a voz como autoridade; como fragmento fonológico significante; ou ainda mera indicação sonora da presença do Outro que deixa rastos de gozo no corpo. Vestígios afônicos, escritos, e que constituem a voz como sedimento do supereu.

$\mathrm{Na}$ atualidade, o corpo tem sido tomado como um objeto não só de interesse da ciência como também dos sujeitos. Ele tanto pode ser tomado como fonte de prazer como de desprazer. O corpo contribui muito para o mal-estar, sentido no corpo como medo. Mas medo do quê? De nosso corpo? Disso que em nosso corpo se manifesta como culpa ou como angústia. Pode ser também um medo de sentir medo como o que acomete alguns sujeitos e que a psiquiatria resolveu chamar com o pomposo nome de 'síndrome do pânico'. ${ }^{3}$ Aqui temos um sujeito que teme ser tomado em seu corpo pelos sintomas do medo. Lançado ao desamparo, à falta de sentido que o terror origina, há o encontro com o não sentido, com o estranho. A vivência do estranhamento diante do familiar é o que podemos assinalar como a base do surgimento da angústia. A angústia é justamente isso que se situa em outra parte em nosso corpo, “é o sentimento que

\footnotetext{
${ }^{3}$ Lembrando que o Deus Pã era aquele que vivia em estado de constante ereção, e que foi recusado por todos os seus supostos pais desde que o verdadeiro não quis saber dele. A tal síndrome "nova" é na verdade mais antiga do que a "ciência moderna" pode alcançar.
} 
surge dessa suspeita que nos assalta por nos reduzirmos ao nosso corpo" (LACAN, 1974/1980, p.182). Considerando a angústia um medo do medo, diremos que é o medo de que a falta falte. E toda a parafernália que a tecnologia põe a serviço do homem não passa de uma tentativa de aplacar a falta, que a angústia denuncia, com objetos que seduzem o sujeito com essa promessa. Como a angústia não o é sem objeto que ameace obturar o sujeito, ocorre que o sujeito se ilude na tentativa de capturar o objeto que lhe falta, daí surgindo a culpa.

No caso das cirurgias plásticas, a psicanálise encontra um grande obstáculo na expectativa alimentada pela ciência de um ideal do corpo, visto como totalidade e não como parcialidade. Esse ideal narcisista vem de encontro à nostalgia humana de integração com a imagem ou com a natureza, buscando a completude da imagem, negando a falta fundamental que nos constitui como sujeitos desejantes. Para evitar o contato com a falta, a tecnologia cria objetos, gadgets. Os gadgets são os bens de consumo que prometem tamponar a falta para produzir bem-estar ou felicidade. Em decorrência de seu uso totalizante, o sujeito fica impedido de entrar em contato com a falta, na sua relação com o objeto a, e submerge frente à abundância dos objetos produzidos pelo capitalismo. É como o uso que se faz de um automóvel como uma falsa mulher: deseja-se que seja o falo, mas é justamente o falo o que nos impede de ter uma relação com algo que seria nossa garantia sexual. O automóvel é a garantia de que cada um fique do seu próprio lado, impedindo-o, porque há falta, de achar-se. Contudo, o totalitarismo dos objetos aponta que não há nenhuma barreira contra o gozo. É justamente isso que levará o sujeito à mortificação porque quanto mais procura nesses objetos um meio de recuar frente às exigências pulsionais, mais o supereu exigirá que compre, e mais continuará insatisfeito.

Nesse ponto, convém distinguir Ideal do Outro de Supereu. No Ideal do Outro destaca-se o significante que identifica e detém. Ligado à produção de sentido e ao desejo, o ideal colabora para que o semblante sustente o sujeito numa cena que contém e circunscreve o gozo, além de organizar para ele a janela de onde vê a realidade. A letra está a serviço da decifração e do sujeito. Ela colabora na construção da realidade psíquica/social.

O supereu, por outro lado, está mais diretamente a serviço da pulsão e do gozo. Ao contrário do Ideal, que funciona segundo o princípio do prazer, o supereu está mais do lado em que a letra resta fora do sentido produzindo apenas gozo. Nesses casos, poderíamos pensar que a função da tatuagem, como escrita, é a de fazer borda, colocando margem para a pulsão (BARROS e OLIVEIRA, 2004), fronteira para o gozo.

Observamos, assim, tatuagens que encobrem quase a totalidade da superfície cutânea recobrindo-a como se fosse preciso refazer toda a extensão da pele. 
Podem parecer, à primeira vista, como excessos. Certamente a época favorece o consumo ao infinito. Numa análise mais detida, porém, podem ser pensadas como formas de inserção social, de construção da realidade psíquica na qual um corpo pode se inserir e transitar sem risco de se perder no Outro gozo. É o caso de um jovem que tatuou seu nome próprio em cada braço e em cada perna para que ele mesmo soubesse que aquele era seu corpo. Ou seja, para poder possuir seu corpo, reconhecê-lo, no campo difuso em que não se separa do Outro.

Excessos como esses só podem ser avaliados caso a caso, mas dão margem a pensar que procuram conter o gozo através de repertório de traços. De forma semelhante ao dos casos em que os sujeitos se cortam compulsivamente e cujo excesso atribuímos aqui como a reiteração de um apelo ao simbólico, diante da falta de uma letra que marque um litoral entre o corpo de gozo e o corpo simbólico, também as tatuagens de aspecto ilimitado podem se dever ao fato, constatável na psicose, de uma necessidade infinita de escoar o gozo justamente porque lhes falta uma escrita matêmica, constante, para circunscrevê-lo.

Em muitos casos, esses atos de escrita suprem a função paterna permitindo àqueles, em que a voz do Outro não escreveu uma identificação unária na carne, a única via vislumbrada de acesso subjetivo ao corpo próprio. Nesses casos, as tatuagens visariam dar conta da falha do Nome-do-Pai como a escrita tão frequentemente o faz na psicose. Caberia à psicanálise propiciar que o sintoma analítico se escreva na experiência, "em função de toda a lógica do dispositivo que põe os ditos do paciente. Trata-se sempre de uma invenção” (CALDAS, 2007, p.151). Mas aqui já valeria a escrita de outro trabalho...

Recebido em 17/3/2010. Aprovado em 25/10/2010. 


\section{REFERÊNCIAS}

ALENCAR NETO, M. \& NAVA, J. (1966). Tatuagens e desenhos cicatriciais. Belo Horizonte: MP/Movimento e Perspectiva.

BAUMAN, Z. (2000). A modernidade líquida. Rio de Janeiro: Jorge Zahar Editor.

BARROS, R. M. M. \& OLIVEIRA, G. F. T. (2004). "As margens da pulsão”, in $O$ corpo do Outro e a criança. Revista da Escola Letra Freudiana, n.33. Rio de Janeiro: Escola Letra Freudiana, p.95-100.

BARTHES, R. (1970/2007). O império dos signos. São Paulo: WMF Martins Fontes.

BORCH-JACOBSEN, M. (1991). Lacan avec les philosophes. Paris: Albin Michel. (Bibliothèque du Collège International de Philosophie).

CALDAS, H. (2007) Da voz à escrita: clínica psicanalítica e literatura. Rio de Janeiro: Contra Capa.

COSTA, A. (2005). Tatuagens e marcas corporais. São Paulo: Casa do Psicólogo.

FREUD, S. (1994). Obras completas. Buenos Aires: Amorrortu.

(1900) "La interpretación de los sueños. II: El método de la interpretación de los sueños”, v.IV, p.118-140.

(1920) “Más allá del principio del placer”, v.XVIII, p.3-62.

. \& BREUER, J. (1895/1994). “Estudios sobre la histeria”, in Obras completas, v. II. Buenos Aires: Amorrortu.

HOLANDA, A. Buarque de (1975). Novo dicionário da língua portuguesa. Rio de Janeiro: Nova Fronteira.

LACAN, J. (1974/1980). “La tercera”. Actas de la Escuela Freudiana de Paris. VII Congresso, Roma. Barcelona: Petrel, p.159-186.

. (1957/1998). "Seminário sobre A carta roubada”, in Escritos. Rio de Janeiro: Jorge Zahar, p.13-66.

(1953/1998). "Função e campo da fala e da linguagem em psicanálise”, in Escritos. Rio de Janeiro: Jorge Zahar, p.238-324.

. (1962-1963/2005). O Seminário, livro 10, A angústia. Rio de Janeiro: Jorge Zahar.

(1964/1988). O Seminário, livro 11, Os quatro conceitos fundamentais da psicanálise. Rio de Janeiro: Jorge Zahar.

. (1969-1970/1992). O seminário, livro 17, O avesso da psicanálise. Rio de Janeiro: Jorge Zahar.

(1971/2009). O seminário, livro 18, De um discurso que não seria do semblante. Rio de Janeiro: Jorge Zahar.

. (1972-1973/1985). O seminário, livro 20: Mais, ainda. Rio de Janeiro:

Jorge Zahar, 2a. ed.

. (1975-76/2007). O seminário, livro 23, O sinthoma. Rio de Janeiro: Jorge Zahar.

(1975) “Conferência na Columbia University”. Scilicet n.6/7. Paris: Seuil.

MILLER, J.-A. (2000) Os seis paradigmas do gozo. Opção Lacaniana, Revista Brasileira Internacional de Psicanálise, n.26/27, p.87-105. 
MILLER, J.-A. (2005) “Introdução à leitura do seminário 'A angústia' de Jacques Lacan”. Opção Lacaniana, Revista Brasileira Internacional de Psicanálise, n.43, p.7-81.

(2008-2009). "Curso de Orientação Lacaniana”: Choses de finesse en Psychanalyse. Aula de 20 de maio de 2009.

SCILICET, v.6/7. (1976) Écriture et sexuation. Paris: Seuil, p.343-355.

\section{Reportagens e filmes}

CAMPION, J. (1993). O piano. Nova Zelândia: Paris Filmes.

Suíços: Paula não estava grávida, O Dia, edição de 14 de fevereiro de 2009.

Os cortes que aliviam a dor da alma, Revista Marie Claire, edição 216, março de 2009.

Rita Manso

ritamanso@globo.com

Heloisa Caldas

helocaldas@terra.com.br 